\title{
Inter-Divisional Group on Experimental Physics Control Systems
}

The general context in which experimental physics is performed to day has changed drastically in the last years. After the golden sixties came the economic depression of the seventies, and public interest shifted gradually from long term physics research to fields that promise quicker return on investment, e.g. molecular biology, space, informatics... More than in the past, experimental physics has thus to compete with other research fields to obtain its share of the national research budgets. As a consequence, physics laboratories now operate with reduced financial and personnal resources. On the other hand, their machines are becoming increasingly complex, relying more and more on complex control systems. The technical demands require systems to be designed that are often at the frontiers of technological progress. As a natural consequence, the controls specialist has also evolved from the all round engineer or physicist who timbered together some "system" in his backyard, to fully identified professional control engineering teams.

Experimental physics controls is thus expanding in a continously tighter economic environment. Because of its increasing complexity and scarcer resources, a strong desire has grown up for more contacts amongst control teams to exchange experience, coordinate prospective research and discuss "family" problems that are out of place in most existing conferences and workshops whose main interest, lies with experimental physics itself. This fact is best illustrated by the two workshops specifically on accelerator controls, that have been organized in the US : at Brookhaven BNL, in January 1985 and at Los Alamos LANL, 7-10 October 1985. At the closing session of the second workshop, all participants indicated a strong interest in repeating such meetings. Further discussions, in particular between European specialists, showed a strong motivation to get themselves organized into a professional group so as to preserve the standard Europe has reached in this specific technology, and there was also the question of an official body to sponsor such a group.

\section{EPS as Sponsoring Organization}

Although experimental physics controls is not a pure physics branch as are those covered by the various EPS Divisions and Sections to date, it was agreed that EPS would be the appropriate society to sponsor the activities of such a group of professionals requiring knowledge in various disciplines: controls, electronics, computer science, because the physics and experimental nature of the processes themselves, their complexity and constraints remain predominant factors in the design of their control systems. With this Council has agreed.

\section{The Group}

The purpose of the Inter-divisional Group is to promote the technology of controls for experimental physics: accelerators, fusion, lasers, experiments... It establishes contacts between specialists in that field in European and nonEuropean Institutions. It stimulates international cooperation and exchange of information; it promotes the efficient use of scarce resources and fosters high standards.

Means to reach these goals are:

- to sponsor and organize conferences, workshops, etc.

- to sponsor and organize investigations for key projects,

- to encourage post graduate training of young university graduates who want to specialize in control engineering by participating in experimental physics control projects,

to fulfil consultancies,

- to collaborate with experimental physics controls groups outside Europe.

\section{The Board}

All matters relating to the Group are handled by a Board whose members are in general leading control groups in major research institutions. Their names will be published in the June (Directory) issue of Europhysic News.

Communication with other laboratories is established through Contact persons who are informed on all matters concerning the Group and the decisions and recommendations made by the Board. They also ensure that the EPCS members in their institution are informed and they keep the Board informed of any significant happenings relating to controls in their home institution.

\section{Membership}

Membership of the Inter-Divisional Group on Experimental Physic Control Systems is open to Individual Ordinary Members of the EPS who are then eligible to be Contact persons. Members can also initiate temporary working groups on specialized subjects. If subject and participants are approved by the IDG on EPCS Board, the working group will be put in touch with other laboratories so as to enlarge its audience and possible field of application.

Registration can be done through one of the Board members, Contact persons in the various institutions, or through the EPS Secretariat in Geneva.

\section{Axel Daneels, CERN} Chairman of the Board

EPS Divisions, Sections and Group
Astronomy and Astrophysics Division
Solar Physics Section
Atomic and Molecular Physics Division
Atomic Spectroscopy Section
Chemical Physics
Electronic and Atomic Collisions
Molecular Physics
Computational Physics Group
Condensed Matter Division
Liquids Section
Low Temperature Physics Section
Macromolecular Physics
Magnetism
Metal Physics
Semiconductors and Insulators
Surfaces and Interfaces
High Energy \& Particle Physics Division
Interdiv. Group on Exptl. Phys. Control Systems
Interdiv. Group on Physics for Development
Nuclear Physics Division
Optics Division
Plasma Physics Division
Quantum Electronics Division

Europhysics News is the official journal of the Eurapean Physical Society which comprises 29 National Societies, Academies and Group, over 3500 Individual Members and 70 Associate Members. Governing bodies of EPS are the General Meeting, Council and an elected Executive Committee responsible for detailed policy. EPS promotes the collaboration of physicists throughEPS promotes the collaboration of physicists through-
out Europe, organising and harmonising conferences and publications, improving physics education, encouraging physics applications, awarding scholarships to sponsored schools in Erice. EPS publishes in addition to Europhys. News, Europhysics Letters (in partnership with national societies). European Journal of Physics (in partnership with The UK Inst. of Phys.), Europhys. lin partnership with The UK Inst. of Phys.), Europhys.
Conf. Abs., Europhys. Ed. News. Individual Members receive Europhys. News free of charge (price to insts. Sw.Fr. 90--la). Europhys. Lett. at Sw.Fr. 55.-la linsts. 550.-), rebates on many other publications and on conference fees. Annual EPS membership fee for Individual Members belonging to an EPS member society is: $\mathrm{S} w$. Fr. 44.-; independent members: Sw.Fr. 132.-; members of a Collaborating Society: Sw.Fr. 55.- (\$26).

\author{
Editor: E.N. Shaw \\ Editorial Board: \\ K. Appert, A. Baratoff, B. Jacrot, \\ F. James, M. Mayor, J. Muller \\ Editorial and Advertising Office at the EPS \\ Secretariat \\ Address: EUROPEAN PHYSICAL SOCIETY \\ P. O. Box 69. \\ CH-1213 Petit-Lancy 2 \\ Switzerland \\ Telephone: Geneva (22) 931130 \\ Telex : 428024 eps ch \\ Cables: europhys genève \\ Printed by: Pfirter frères sa \\ $\mathrm{CH}-1213$ Petit-Lancy/Switzerland
}

